\title{
Aberrant DNA Methylation under Conditions of Thymine Deprivation in Bacillus subtilis
}

\author{
By R. N. BUICK* AND W. J. HARRIS \\ Department of Biochemistry, University of Aberdeen, Marischal College, \\ Aberdeen $A B 9$ I $A S$
}

(Received 21 March 1975; revised I4 May 1975)

\begin{abstract}
SUMMARY
A study has been made of the levels of 6-methylaminopurine and 5-methylcytosine in the DNA of Bacillus subtilis during thymine deprivation. While DNA synthesis was inhibited by thymine deprivation, DNA methylation continued. Base analysis indicated that this aberrant methylation involved an increase solely in the amount of 5-methylcytosine. These aberrant 5-methylcytosine residues were removed from the DNA during continued growth of bacteria in medium lacking thymine. In contrast, 5-methylcytosine residues synthesized during normal growth were relatively unaffected by thymine deprivation. The results are interpreted to indicate that the extensive DNA damage which occurs during thymine deprivation is due in part to exonuclease digestion of regions of DNA containing aberrant 5-methylcytosine residues.
\end{abstract}

\section{INTRODUCTION}

Under a number of circumstances where net synthesis of DNA is inhibited, aberrant DNA methylation has been shown to occur (Theil \& Zamenhof, 1963; Whitfield \& Billen, I972; Ryan \& Borek, I97I). Ryan \& Borek (I97I) demonstrated that in Escherichia coli, DNA methylation continues after DNA synthesis is completely inhibited by u.v. irradiation. These authors suggested that some damage other than thymine dimers, such as single-strand breaks inflicted on the DNA by irradiation, could eliminate the normal restrictions on the specificity of DNA methylases. Gold \& Hurwitz (1963) found that DNA extracted from $E$. coli during thymine starvation had lost the ability to serve as a substrate for $E$. coli DNA methylases in vitro, and suggested that this could be due to over-methylation of DNA during thymine starvation.

Previous studies from this laboratory (Buick \& Harris, 1975) have demonstrated that single-strand gaps accumulate within the DNA of Bacillus subtilis during thymine deprivation. To investigate the possibility that aberrant methylation plays a role in the formation of this damage, we have studied DNA methylation in B. subtilis 2337 during thymine deprivation.

\section{METHODS}

Materials. The following compounds were obtained from the Radiochemical Centre, Amersham, Buckinghamshire: $\left[8{ }^{3} \mathrm{H}\right]$ adenine $\left(\left[{ }^{3} \mathrm{H}\right] \mathrm{Ade} ; 27 \mathrm{Ci} / \mathrm{mmol}\right), \mathrm{L}-\left[\mathrm{Me}-{ }^{3} \mathrm{H}\right]$ methionine $\left(\left[{ }^{3} \mathrm{H}\right] \mathrm{Met} ; 2.9 \mathrm{Ci} / \mathrm{mmol}\right)$, and S-adenosyl $\mathrm{L}-\left[\mathrm{Me}^{3} \mathrm{H}\right]$ methionine $\left(\left[{ }^{3} \mathrm{H}\right] \mathrm{SAM} ; 8.9 \mathrm{Ci} /\right.$ $\mathrm{mmol}$ ). Dowex ion-exchange resin AG50 $\times 8$ (200 to 400 mesh) was obtained from Bio-Rad Laboratories, St Albans, Hertfordshire. Cellulose phosphate paper (P8I) was a product of Whatman, and Soluene $\mathrm{TM}_{\mathbf{1 0 0}}$ was obtained from Packard Instrument Ltd.

* Present address: McArdle Laboratory for Cancer Research, University of Wisconsin, Madison, Wisconsin, U.S.A. 
Growth of bacteria. The bacterial strain used for this work was Bacillus subtilis 2337 (thy met ilv) and was obtained from Dr J. Gross. Bacteria from tryptose blood agar base (Oxoid) were inoculated into growth medium and shaken overnight (I4 to $17 \mathrm{~h}$ ) at $37^{\circ} \mathrm{C}$. This stationary-phase culture was then diluted tenfold into fresh growth medium. Small volumes of cells were grown in $5 \mathrm{ml}$ batches as previously described (Buick \& Harris, 1975). Large volumes of cells were grown in an orbital incubator (100 rev./min) at $37^{\circ} \mathrm{C}$ in $250 \mathrm{ml}$ or I 1 Erlenmeyer flasks. Such cultures reached mid-exponential phase in $3.5 \mathrm{~h}$. The minimal medium of Anagnostopoulos \& Spizizen (I96I) was employed, supplemented with $0.02 \%$ (w/v) casein hydrolysate and $10 \mu \mathrm{g}$ thymine $/ \mathrm{ml}$.

Bacteria in mid-exponential phase were washed free of thymine by centrifugation ( $5 \mathrm{~min}$ at $4{ }^{\circ} \mathrm{C}, 2700 \mathrm{~g}$ ) and resuspension in $3 \times 50 \mathrm{ml}$ iced minimal medium. The bacteria were finally resuspended in pre-warmed medium lacking thymine. The time taken for this procedure was approximately $20 \mathrm{~min}$.

Radioactive labelling of cells for analysis of minor methylated bases. Radioactive labelling was routinely carried out in $200 \mathrm{ml}$ samples. $\left[{ }^{3} \mathrm{H}\right] \mathrm{Met}$ was either present throughout growth $(2 \mu \mathrm{Ci} / \mathrm{ml})$ or was given' in short pulses of $30 \mathrm{~min}(10 \mu \mathrm{Ci} / \mathrm{ml})$. In all cases, sodium formate was also added (final concentration $20 \mathrm{~mm}$ ), to minimize incorporation of radioactivity through C-I metabolism. Radioactive labelling was terminated by the addition of $10 \mu \mathrm{g}$ L-methionine/ml.

Preparation of DNA. DNA was prepared by a modification of the methods of Kirby (1957, 1958). Cells were harvested and washed four times at $4{ }^{\circ} \mathrm{C}$ with saline-EDTA (0.10 M-NaCl, 0.0I M-EDTA, pH 8.0). Each gram wet weight of cells was finally suspended in $8 \mathrm{ml}$ saline-EDTA and lysozyme was added to $150 \mu \mathrm{g} / \mathrm{ml}$ final concentration. After incubation at $37^{\circ} \mathrm{C}$ for $15 \mathrm{~min}, 500 \mu \mathrm{g}$ calf thymus DNA was added. 4-Aminosalicylate was added to $6 \%(\mathrm{w} / \mathrm{v})$ and an equal volume of phenol-hydroxyquinoline ( $90 \mathrm{~g}$ phenol to which was added $10 \mathrm{ml}$ water and $0.1 \mathrm{~g}$ hydroxyquinoline), and the mixture shaken for $15 \mathrm{~min}$. The phases were separated by centrifugation at $7^{\circ} \mathrm{C}$ and $2700 \mathrm{~g}$ for $20 \mathrm{~min}$, the upper aqueous layer removed and the DNA precipitated with 2 volumes of ethanol. The DNA fibres were washed in ethanol, redissolved in 0.0I M-sodium acetate, reprecipitated with ethanol and redissolved in $0.5 \mathrm{ml}$ saline-citrate (0.15 $\mathrm{M}-\mathrm{NaCl}, 0.015 \mathrm{M}$-sodium citrate, pH 7.0). Ribonuclease (deoxyribonuclease-free) was added to $200 \mu \mathrm{g} / \mathrm{ml}$, incubated for I $5 \mathrm{~min}$ at $37^{\circ} \mathrm{C}$ and then protease (deoxyribonuclease-free) added to $200 \mu \mathrm{g} / \mathrm{ml}$ final concentration. After $15 \mathrm{~min}$ at $37^{\circ} \mathrm{C}$, the DNA was precipitated with ethanol and dried in a vacuum desiccator before hydrolysis at $37^{\circ} \mathrm{C}$ for $\mathrm{I} \mathrm{h}$ in $0.3 \mathrm{M}-\mathrm{KOH}$. After neutralization, the DNA was precipitated with ethanol and dried.

Preparation of DNA hydrolysates for chromatography. Hydrolysis of the dried DNA was performed in perchloric acid $(10 \mathrm{M})$ for $\mathrm{I} \mathrm{h}$ at $100^{\circ} \mathrm{C}$. The digest was neutralized by the addition of $\mathrm{KOH}$ and clarified by centrifugation.

Dowex $50 \times 8$ cation exchange resin has been used for the purification and fractionation of DNA hydrolysates (Magee \& Faber, 1962). In this case, the DNA hydrolysates were purified by Dowex $50 \times 8$ cation exchange resin in order to improve the resolution of the final chromatographic separation.

The Dowex $50 \times 8$ resin $\left(\mathrm{H}^{+}\right.$form; 200 to $\left.400 \mathrm{mesh}\right)$ was packed in $0.5 \times 8 \mathrm{~cm}$ columns. After washing the column with $10 \mathrm{ml}$ of $4 \mathrm{M}-\mathrm{HCl}$, the neutralized hydrolysates were loaded in $0.5 \mathrm{M}-\mathrm{HCl}$ and then sequentially eluted with $0.5 \mathrm{M}-\mathrm{HCl}$ (IO ml) and $4 \mathrm{M}-\mathrm{HCl}$ (I $5 \mathrm{ml}$ ). The sample eluted by $4 \mathrm{M}-\mathrm{HCl}$ was rotary evaporated to dryness and the resulting residue dissolved in $40 \mu \mathrm{l}$ of $0.5 \mathrm{M}-\mathrm{HCl}$.

Analysis of minor methylated bases. The one-dimensional chromatography technique of 
Table 1. The extent of methylation during incubation in the presence and absence of thymine

Bacteria $(5 \mathrm{ml})$ in mid-exponential phase of growth were subjected to thymine deprivation in $4 \times 5 \mathrm{ml}$ cultures at an initial concentration of $10^{6}$ bacteria $/ \mathrm{ml}$. Radioactive precursors $(2 \mu \mathrm{Ci}$ $\left[{ }^{3} \mathrm{H}\right] \mathrm{Met}$, or $0 \cdot 2 \mu \mathrm{Ci}\left[{ }^{3} \mathrm{H}\right] \mathrm{Ade} / \mathrm{ml}$, as indicated) were added at the start of thymine deprivation. All cultures were incubated for $\mathbf{2} \mathrm{h}$ before cell lysates were prepared as described previously (Buick \& Harris, 1975). Lysates were analysed within $\mathrm{CsCl}$ equilibrium density gradients, $\mathrm{pH} 8.0$ (Harris \& Barr, I97I), and fractions containing DNA were pooled and dialysed overnight against salinecitrate. DNA concentration was determined from $E_{260 \mathrm{~m}}$, and radioactivity from portions TCAprecipitated within glass fibre filter discs. Results are expressed as calculated specific activities.

\begin{tabular}{|c|c|c|c|}
\hline & $\begin{array}{l}\text { Radioactive } \\
\text { precursor }\end{array}$ & $\begin{array}{r}\text { C.p.m./ } \\
\mu \mathrm{g} \text { DNA }\end{array}$ & $\begin{array}{l}{\left[{ }^{3} \mathrm{H}\right] \mathrm{Met} /} \\
{\left[{ }^{3} \mathrm{H}\right] \text { Ade }}\end{array}$ \\
\hline Without thymine & $\begin{array}{l}{\left[{ }^{3} \mathrm{H}\right] \text { Met }} \\
{\left[{ }^{3} \mathrm{H}\right] \text { Ade }}\end{array}$ & $\begin{array}{r}54 \\
158\end{array}$ & 0.345 \\
\hline With thymine & $\begin{array}{l}{\left[{ }^{3} \mathrm{H}\right] \text { Met }} \\
{\left[^{3} \mathrm{H}\right] \text { Ade }}\end{array}$ & $\begin{array}{r}385 \\
11850\end{array}$ & 0.0325 \\
\hline
\end{tabular}

Rubery \& Newton (197I) was employed. This uses Whatman P8I cellulose phosphate paper $(46 \times 57 \mathrm{~cm})$ with an eluting solvent of isopropanol-I2 $\mathrm{M}$-HCl-water (I70:44:36, by vol.). Chromatograms were developed by descending chromatography for approximately $18 \mathrm{~h}$. Developed chromatograms were cut into $\mathrm{I} \times 0.5 \mathrm{~cm}$ pieces and placed in glass scintillation vials. Soluene $\mathrm{TM}_{100}(100 \mu \mathrm{l})$ was added to each vial and heated at $60^{\circ} \mathrm{C}$ for $\mathrm{I} \mathrm{h}$ before the addition of $2 \mathrm{ml}$ scintillation fluid [0.75 g dimethyl I,4-bis-(5-phenyloxazol-2-yl)benzene and $12.5 \mathrm{~g} \mathrm{2,5}$-diphenyloxazole dissolved in 2.51 toluene].

Measurement of DNA methylase activity. Cells were harvested and washed twice with methylation buffer (0.02 M-tris, $0.001 \mathrm{M}-\mathrm{MgCl}_{2}, 0.002 \mathrm{M}$-EDTA, $0.001 \mathrm{M}$-2-mercaptoethanol, $\mathrm{pH} 8 \cdot 5$ ). Each gram wet weight of cells was finally suspended in $8 \mathrm{ml}$ methylation buffer, lysozyme was added to $150 \mu \mathrm{g} / \mathrm{ml}$ final concentration and the mixture incubated at $37^{\circ} \mathrm{C}$ for $15 \mathrm{~min}$. Cell-free extracts were obtained by centrifugation for $\mathrm{I} \mathrm{h}$ at $4{ }^{\circ} \mathrm{C}$ and $100000 \mathrm{~g}$.

DNA methylase assays were performed in a total volume of $0.25 \mathrm{ml}$ containing tris, pH 8.0 (Io $\mu \mathrm{mol}$ ), $\mathrm{MgCl}_{2}$ (I $\mu \mathrm{mol}$ ), 2-mercaptoethanol ( $4 \mu \mathrm{mol}$ ), calf-thymus DNA (I00 nmol as nucleotide residues), [ $\left.{ }^{3} \mathrm{H}\right] \mathrm{SAM}$ ( $10 \mathrm{nmol}, 10^{5}$ d.p.m./nmol), and enzyme extract $(\mathrm{O} \cdot \mathrm{I} \mathrm{ml})$.

Incubation $\left(37^{\circ} \mathrm{C}\right.$ for $30 \mathrm{~min}$ ) was stopped by chilling and the addition of $0.2 \mathrm{ml} 0.1$ M-sodium pyrophosphate, $0.3 \mathrm{ml} 5 \mathrm{M}$-sodium perchlorate, $\mathrm{O} . \mathrm{I} \mathrm{ml}$ bovine serum albumin ( $10 \mathrm{mg} / \mathrm{ml}$ ), and $\mathrm{I} \mathrm{ml} 10 \%$ (w/v) trichloroacetic acid (TCA) containing $0.01 \mathrm{M}$-sodium pyrophosphate. The precipitate was washed three times by centrifugation and resuspension in $5 \%(\mathrm{w} / \mathrm{v})$ TCA containing $2 \mathrm{mM}$-sodium pyrophosphate, and then collected by filtration through $2.5 \mathrm{~cm}$ Whatman glass fibre discs (GF/C). After washing with $2 \times 20 \mathrm{ml}$ volumes

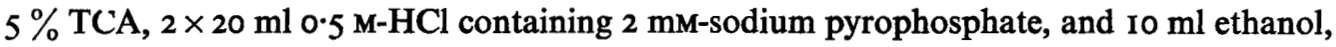
the filters were dried and counted in $2 \mathrm{ml}$ scintillation fluid. Protein concentration was determined as described by Lowry et al. (195I).

\section{RESULTS}

\section{Effect of initial bacterial concentration on the kinetics of thymineless death}

The kinetics of thymineless death in B. subtilis 2337 were dependent on the initial bacterial concentration. The maximum rate of killing occurred at an initial concentration of $10^{6}$ bacteria/ml, the concentration used in previous studies (Buick \& Harris, 1975). 


\section{Table 2. Ratios of 6-MAP to 5-MC in DNA during thymine deprivation}

Bacteria in mid-exponential phase were subjected to thymine deprivation at an initial concentration of $10^{8} / \mathrm{ml}$. Methionine was added to cell samples, and DNA prepared as described in Methods. Base analysis was performed as described in Methods. The amount of material applied to any chromatogram was determined by the radioactivity in the sample, and does not reflect the amount of radioactivity incorporated by a fixed volume of bacteria. Fractions containing 6-MAP and 5-MC were pooled and total radioactivity measured.

$\begin{array}{lccc}\begin{array}{c}\text { Time of contact } \\ \left.\text { with [ }{ }^{3} \mathrm{H}\right] \mathrm{Met}\end{array} & \begin{array}{c}\text { 6-MAP } \\ \text { (c.p.m.) }\end{array} & \begin{array}{c}\text { 5-MC } \\ \text { (c.p.m.) }\end{array} & \text { 6-MAP/5-MC } \\ \begin{array}{l}\text { With thymine* } \\ \text { Continuous contact }\end{array} & \mathrm{I} 295 & 300 & 4.32 \\ \text { Without thymine } \dagger & & & \\ 0-0.5 \mathrm{~h} & 760 & 160 & 4.75 \\ 0.5-\mathrm{I} \mathrm{h} & 825 & 750 & \mathrm{I} \cdot 10 \\ \mathrm{I}-\mathrm{I} \cdot 5 \mathrm{~h} & 678 & 930 & 0.73 \\ 1.5-2 \mathrm{~h} & 1040 & 450 & 2.3 \mathrm{I} \\ 2-2.5 \mathrm{~h} & 790 & 195 & 4.05\end{array}$

* $\left[{ }^{3} \mathrm{H}\right] \mathrm{Met}(2 \mu \mathrm{Ci} / \mathrm{ml})$ and sodium formate $(20 \mathrm{~mm})$ were added, from 0 to $2.5 \mathrm{~h}$.

$\dagger\left[{ }^{3} \mathrm{H}\right] \mathrm{Met}(10 \mu \mathrm{Ci} / \mathrm{ml})$ and sodium formate $(20 \mathrm{~mm})$ were added, for the times indicated.

However, to analyse minor methylated bases, it was found necessary in the present study to resuspend bacteria at an initial concentration of $10^{8} / \mathrm{ml}$. Bacteria undergo an extremely low rate of thymineless death under these conditions (approximately $70 \%$ viability remaining after $6 \mathrm{~h}$, compared with $2 \%$ viability when they are resuspended at an initial concentration of $\left.10^{6} / \mathrm{ml}\right)$. We attribute this slow rate of death in part to the inefficiency of aeration at such a high concentration, and in part to the lack of removal of thymine by centrifugal washing procedures, which are less efficient than the filtration washing procedures described previously (Buick \& Harris, 1975).

\section{Effect of thymine deprivation upon DNA methylation}

The stoichiometry between DNA synthesis and DNA methylation is altered when DNA synthesis is inhibited by thymine deprivation. DNA from cells grown in the absence of thymine was over-methylated approximately tenfold (Table $\mathrm{I}$ ). The specificity of the bases methylated during normal growth is illustrated by Fig. I. Both 6-methylaminopurine (6-MAP) and 5-methylcytosine (5-MC) were normally present, in the ratio 4: $\mathrm{I}$. The radioactivity incorporated into the adenine-guanine position of the chromatogram can be explained by the effects of C-I metabolism. The presence of 20 mM-sodium formate was not sufficient to abolish all such incorporation. However, higher concentrations reduced bacterial viability. The radioactivity with the cytosine position was approximately constant in different experiments and appeared to be caused by alkaline treatment of the DNA before hydrolysis.

\section{Aberrant methylation of DNA during thymine starvation}

Analysis of DNA extracted from bacteria during thymine deprivation showed that the ratio of 6-MAP to 5-MC changed during the course of thymine starvation (Table 2). The ratio dropped from the normal level of 4.3 to 0.7 during the period $\mathrm{I}$ to $\mathrm{I} \cdot 5 \mathrm{~h}$ of thymine deprivation, and returned to normal at later stages. These results suggest a transient increase in the amount of 5-MC in the DNA.

The stability of the 5-MC was examined (Fig. 2). The radioactivity incorporated into 


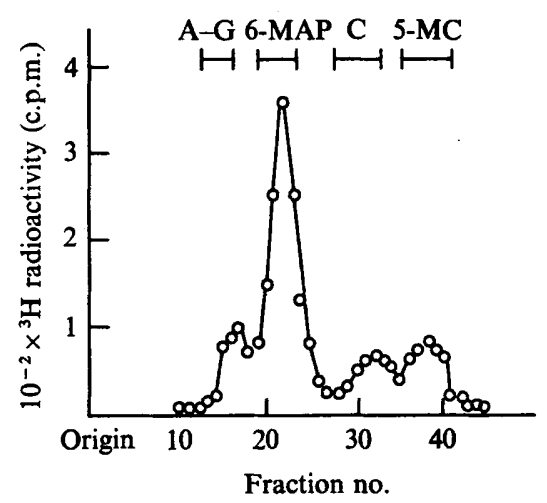

Fig. I

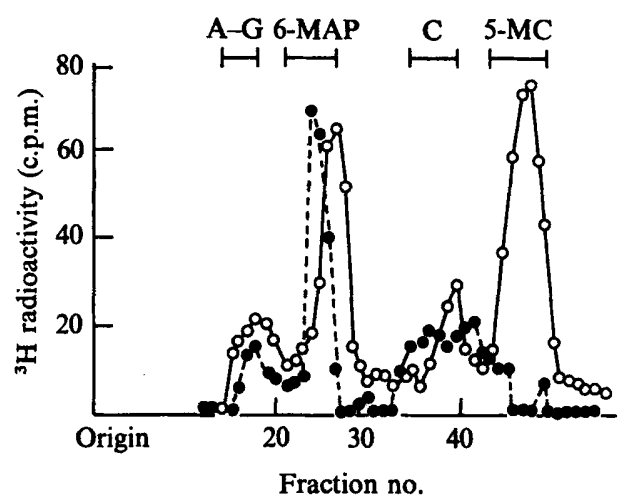

Fig. 2

Fig. I. Chromatography of DNA hydrolysates from bacteria grown with $\left[{ }^{3} \mathrm{H}\right] \mathrm{Met}$. Bacteria (50 $\left.\mathrm{ml}\right)$ were grown to early stationary phase in medium containing $\left[{ }^{3} \mathrm{H}\right] \mathrm{Met}(2 \cdot 0 \mu \mathrm{Ci} / \mathrm{ml})$ and sodium formate $(20 \mathrm{~mm})$. Preparation of DNA and base analysis were performed as described in Methods. Samples of pure bases were co-chromatographed and identified by u.v. absorption.

Fig. 2. Stability of 5-MC produced at an early stage of thymine deprivation. [ $\left.{ }^{3} \mathrm{H}\right] \mathrm{Met}(10 \mu \mathrm{Ci} / \mathrm{ml})$ and sodium formate (20 mM) were added to a $200 \mathrm{ml}$ culture of bacteria which had been deprived of thymine for $0.5 \mathrm{~h}$. After $\mathrm{I} \mathrm{h}$ further incubation, $100 \mathrm{ml}$ of bacteria were removed and DNA prepared (O). L-methionine $(10 \mu \mathrm{g} / \mathrm{ml})$ was added to the remaining bacteria, and incubation in the absence of thymine continued for $2.5 \mathrm{~h}$, at which time DNA was prepared (O).

A-G, 6-MAP, C and 5-MC indicate the positions of adenine-guanine, 6-MAP, cytosine and 5-MC, respectively.

Table 3. Stability of methylated bases produced during normal growth to subsequent thymine starvation of bacteria

A $250 \mathrm{ml}$ culture of bacteria was grown to mid-exponential phase in medium containing [ $\left.{ }^{\mathrm{s}} \mathrm{H}\right] \mathrm{Met}$ $(2 \mu \mathrm{Ci} / \mathrm{ml})$ and sodium formate $(20 \mathrm{~mm})$. A sample of bacteria was removed immediately, and the remaining cells subjected to thymine deprivation at an initial cell concentration of $10^{8} / \mathrm{ml}^{\text {for }} 4 \mathrm{~h}$. Base analyses were performed on both samples as described in Methods.

$\begin{array}{cccc}\begin{array}{c}\text { Time of incubation in } \\ \text { thymineless medium }\end{array} & \begin{array}{c}\text { 6-MAP } \\ \text { (c.p.m.) }\end{array} & \begin{array}{c}\text { 5-MC } \\ \text { (c.p.m.) }\end{array} & \text { 6-MAP/5-MC } \\ \text { oh } & 4568 & 1102 & 4.15 \\ 4 \mathrm{~h} & 4428 & 1135 & 3.90\end{array}$

5-MC during the first $90 \mathrm{~min}$ of thymine deprivation was subsequently removed, whereas the radioactivity simultaneously incorporated into 6-MAP was stable. Furthermore, radioactivity incorporated into $5-\mathrm{MC}$ before thymine deprivation was stable to subsequent thymine deprivation (Table 3 ).

\section{DNA methylase activity during thymine deprivation}

At the time at which bacteria were normally harvested for subsequent thymine deprivation $(3.5 \mathrm{~h})$, the DNA methylase activity of crude extracts was substantial (Table 4 ). However, these same cells had no DNA methylase activity after washing (o h, Table 4$)$, implying that the washing procedure either removed or inactivated DNA methylase activity. On subsequent incubation in medium lacking thymine, the specific activity of the DNA methylase was seen to increase to a maximum at $\mathrm{I} h$ and then to decrease. The maximum level of DNA methylase activity during thymine deprivation was similar to the level in exponentially-grown bacteria. 


\section{Table 4. Effect of thymine starvation on DNA methylase activity in bacteria}

Cells in mid-exponential phase of growth $(3.5 \mathrm{~h})$ were subjected to thymine deprivation at an initial concentration of $10^{8} / \mathrm{ml}$ in a $250 \mathrm{ml}$ culture. Samples of bacteria $(50 \mathrm{ml})$ were removed at intervals and the amount of $\left[{ }^{3} \mathrm{H}\right] \mathrm{SAM}$ incorporated into calf-thymus DNA by cell extracts measured as described in Methods.

$\begin{array}{cc}\begin{array}{c}\text { Time of preparation } \\ \text { of extract (h) }\end{array} & \begin{array}{c}\text { Specific activity of DNA methylase } \\ \left.\text { (pmol [ }{ }^{3} \mathrm{H}\right] \mathrm{SAM} \text { incorporated/h/mg protein) }\end{array} \\ \begin{array}{c}\text { (Mid-exponential } \\ \text { phase bacteria) }\end{array} & (45 \cdot 0) \\ 0 & 0 \\ \text { I } & 34 \cdot 6 \\ 2 & 21 \cdot 1 \\ 3 & 18 \cdot 8 \\ 4 & 6 \cdot 1\end{array}$

\section{Table 5. Base ratios of DNA methylated in vitro}

Enzyme extracts were prepared from bacteria at $4 \mathrm{~h}$ of growth in complete medium, and from cells after $I \mathrm{~h}$ incubation in medium lacking thymine. Assays using calf-thymus DNA as template were scaled up fivefold from that described in Methods. The reaction was stopped after $30 \mathrm{~min}$ by the addition of I $\mathrm{mg}$ calf-thymus DNA and the DNA precipitated with 2 vol. ethanol. Base analysis was performed as described in Methods.

\begin{tabular}{|c|c|c|c|}
\hline & $\begin{array}{l}\text { 6-MAP } \\
\text { (c.p.m.) }\end{array}$ & $\begin{array}{c}\text { 5-MC } \\
\text { (c.p.m.) }\end{array}$ & 6-MAP/5-MC \\
\hline \multicolumn{4}{|c|}{ Enzyme extracted from bacteria grown: } \\
\hline With thymine & 410 & 263 & $I \cdot 56$ \\
\hline Without thymine & 358 & 252 & $1 \cdot 42$ \\
\hline
\end{tabular}

A comparison of the in vitro specificity of enzyme extracts prepared from mid-exponential bacteria, and bacteria after $\mathrm{I} h$ of thymine deprivation, is shown in Table 5 , from which it can be seen that the relative labelling of 6-MAP and 5-MC in calf-thymus DNA was the same for both enzyme extracts.

\section{DISCUSSION}

The stoichiometry between DNA synthesis and DNA methylation in $E$. coli is altered by u.v. irradiation (Ryan \& Borek, 1971) and by X-irradiation (Whitfield \& Billen, 1972). Table I demonstrates a similar situation when DNA synthesis was inhibited by thymine starvation of $B$. subtilis 2337. The ratio of DNA methylation to DNA synthesis was apparently increased tenfold by depriving cells of thymine. The interpretation of these results is dependent upon the assumption that the specific activities of radioactive precursors were identical in the corresponding incubations.

The occurrence of aberrant methylation is confirmed by Table 2 and Fig. 2, which suggest a transient increase in the amount of 5-MC within the DNA. This 5-MC was subsequently removed by further incubation under conditions of thymine deprivation, whereas 5-MC residues synthesized during normal growth were relatively stable to subsequent thymine starvation (Table 3 ).

Possible explanations for this aberrant methylation are (i) the process of thymine deprivation results in the expression of a new, previously unexpressed enzyme activity, or (ii) the aberrant methylation is due to a change in the site of action of existing DNA methylases.

With regard to (i), it is important to note that the procedure of washing mid-exponential cells before thymine deprivation resulted in the removal of the high levels of DNA methylase 
activity (Table 4). Thus DNA methylases were synthesized during the initial stages of thymine starvation, and the level of enzyme activity was restored to that within normal cells. Tweats, Pinney \& Smith (1974) observed the induction of R-factor coded nuclease by thymine deprivation of $E$. coli. Since it is likely that separate enzyme systems exist for the synthesis of 6-MAP and 5-MC (Fujimoto, Srinivasan \& Borek, 1965), it is possible that during the initial stages of thymine starvation a new DNA methylase, specific for cytosine, was expressed. However, the finding that enzyme extracts from mid-exponential and thymine-starved bacteria catalyse the methylation of both adenine and cytosine of calfthymus DNA to the same extent in vitro, is highly suggestive that both enzyme preparations contain the same enzyme species (Table 5). Also, the expression of a new enzyme does not explain the instability of the 5-MC residues. Clearly, definitive evidence for or against this possibility will be provided only by the purification of these enzyme activities.

With regard to (ii), evidence has been presented (Buick \& Harris, 1975) that in this strain of $B$. subtilis, single-strand breaks accumulate during the initial stages of thymine deprivation, breaks which subsequently extend into gaps. Single-strand breaks could thus serve as a site of action for the 5-MC synthesizing enzyme, and such aberrant 5-MC residues could act as a recognition site for cellular exonucleases, resulting in the removal of the 5-MC residue and a number of associated bases. In support of this is the finding of Gold \& Hurwitz (1964), that the introduction of single-strand breaks into calf-thymus DNA by treatment with pancreatic DNAase I increased the rate of methylation of this DNA when subsequently used as a substrate for DNA methylases in vitro. Furthermore, nucleases which specifically recognize single-strand breaks with an adjacent aberrantly-methylated base (as introduced by treatment with methylmethanesulphonate), have been described from B. subtilis and M. lysodeikticus (Strauss, 1962; Reiter \& Strauss, 1965; Reiter et al. 1967; Strauss, Coyle \& Robbins, 1968). It is our hypothesis, therefore, that the accumulation of single-strand gaps within $B$. subtilis during thymine deprivation (Buick \& Harris, 1975) is due, at least in part, to methylation of single-strand breaks, and the subsequent recognition of this abnormality by exonuclease.

Evidence has been presented (Buick \& Harris, 1975) that on restoration of thymine to thymine-starved cells, both DNA replication and the repair of single-strand gaps are initiated simultaneously, and when a replication fork reaches a gap before it is repaired, doublestrand breakage of the chromosomes occurs. This is a possible cause of lethality within these cells. Freifelder (1967) presented indirect evidence that in $E$. coli $\mathrm{B} / \mathrm{r}$, prevention of DNA methylation had no effect on the survival of bacteria during thymine starvation. This suggests that DNA methylation is not the primary cause of thymineless death. If our hypothesis is correct, then DNA methylation could increase the frequency of lethality within a population by causing the formation of larger single-strand gaps, which would presumably take longer to repair than small gaps. This presumably would increase the probability of a replication fork reaching an incompletely-repaired single-strand gap.

We acknowledge with thanks the support of the Medical Research Council. 


\section{REFERENCES}

Anagnostopoulos, C. \& Spizizen, J. (1961). Requirements for transformation in Bacillus subtilis. Journal of Bacteriology 8r, 741-746.

BuICK, R. N. \& HARris, W. J. (1975). Thymineless death in Bacillus subtilis. Journal of General Microbiology 88, I I 5-I 22 .

FreIFELDER, D. (1967). Lack of a relation between deoxyribonucleic acid methylation and thymineless death in E. coli. Journal of Bacteriology 93, 1732-1733.

Fujimoto, D., Srinivasan, P. R. \& Borek, E. (I965). On the nature of deoxyribonucleic acid methylases. Biological evidence for the multiple nature of the enzymes. Biochemistry 4, 2849-2855.

Gold, M. \& Hurwitz, J. (1963). The enzymic methylation of nucleic acids. Cold Spring Harbor Symposia on Quantitative Biology 28, 149-156.

Gold, M. \& HURWITZ, J. (I964). The enzymic methylation of ribonucleic acid and deoxyribonucleic acid. Journal of Biological Chemistry 239, 3866-3874.

Harris, W. J. \& BARR, G. C. (197I). Structural features of DNA in competent Bacillus subtilis. Molecular and General Genetics 113, 316-330.

KIRBY, K. S. (1957). A new method for the isolation of deoxyribonucleic acids: evidence on the nature of bonds between DNA and protein. Biochemical Journal 66, 495-504.

KIRBY, K. S. (1958). Preparation of some DNA-protein complexes from rat liver homogenates. Biochemical Journal 70, 260-265.

Lowry, O. H., Rosebrough, N. J., Farr, A. L. \& Randall, R. J. (I95I). Protein measurement with the Folin phenol reagent. Journal of Biological Chemistry 193, 265-275.

Magee, P. N. \& FABER, E. (1962). Toxic liver injury and carcinogenesis: methylation of rat liver nucleic acids by dimethylnitrosamine in vivo. Biochemical Journal 83, I 14-124.

Reiter, H. \& Strauss, B. (1965). Repair of damage induced by a monofunctional alkylating agent in a transformable, ultraviolet sensitive strain of Bacillus subtilis. Journal of Molecular Biology 14, 179-194.

Reiter, H., Strauss, B., Robbins, M. \& Maroone, R. (1967). Nature of the repair of methylmethanesulphonate induced damage in Bacillus subtilis. Journal of Bacteriology 93, 1056-1062.

RUBery, E. D. \& Newton, A. A. (I97I). A simple paper chromatographic method for separation of methylated adenines and cytosine from the major bases found in nucleic acids. Analytical Biochemistry 42 , 149-154.

RYAN, A. M. \& BOREK, E. (I97I). Methylation of DNA in ultra-violet irradiated bacteria. Biochimica et biophysica acta 240, 203-214.

STRauss, B. (1962). Differential destruction of the transforming activity of damaged deoxyribonucleic acid by a bacterial enzyme. Proceedings of the National Academy of Sciences of the United States of America 48, 1670-1675.

Strauss, B., Coyle, M. \& Robbins, M. (1968). Alkylation damage and its repair. Symposia on Quantitative Biology 33, 277-287.

Theil, E. C. \& ZAMENhof, S. (1963). Studies on 6-methylaminopurine in bacterial DNA. Journal of Biological Chemistry 238, 3058-3064.

Tweats, D. J., Pinney, R. J. \& SMith, J. T. (1974). R-factor mediated nuclease activity involved in thymineless elimination. Journal of Bacteriology $118,790-795$.

Whitfield, B. L. \& BILlen, D. (1972). In vivo methylation of $E$. coli DNA following U.V. and X-irradiation. Journal of Molecular Biology 63, 363-372. 